defects may be reconstructed in a single procedure with well vascularised tissue and minimal upset to the donor site. This is particularly useful for mandibular and intraoral defects but has many other applications in the head and neck. The concept of functional free muscle transfer-in which a muscle is moved to a new site, revascularised, and reinnervated by microsurgical techniques-allows dynamic reconstruction for facial palsy. ${ }^{112}$ Tissue expansion-a remarkably simple idea in which a silicone bag slowly filled with saline through a subcutaneous valve is used to stretch skin-allows some defects to be filled by local tissues rather than by a distant flap. ${ }^{13}$ It may be combined with traditional techniques. For example, if the skin of the forehead is to be used to reconstruct a large nasal defect expansion of the donor site beforehand will facilitate its direct closure, so eliminating the need for an ugly skin graft in an obvious site.

The past 15 years have seen radical developments in reconstructive methods. The full range of available skills can be offered only by specialist units, but patients, especially children, gain most if they are seen at an early stage since the timing of surgery may have a critical effect on the end result.

BARRY M JONES

Consultant Plastic and Reconstructive Surgeon,

Centre for Facial Anomalies,

Hospital for Sick Children,

Great Ormond Street,

London WCIN 3JH

1 Bhishagratna KKL. The susruta samhita. Calcutta: Bose, 1907.

2 Tessier P, Guiot G, Rougerie J, Delbet JP, Pastoriza J. Ostéotomies cranio-nasio-orbitales. Hypertélorisme. Ann Chir Plast 1967;12:103-18.

3 Whitaker LA, Schuy L, Kerr L. Early surgery for isolated craniofacial dysostosis. Plast Reconstr Surg 1977:60:575-81.

4 Marchac D, Renier D. Le front flottant, traitement précoce des faciocraniosténoses. Ann Chir Plast 1979;24:121-6.

5 Renier D, Sainte-Rose C, Marchac D, Hirsch JF. Intracranial pressure in craniostenosis. $\mathcal{f}$ Neurosurg 1982;57:370-7.

6 Hemmy DC, David DJ, Herman GT. Three dimensional reconstruction of craniofacial deformity using computed tomography. Neurosurgery 1983;13:534-41.

7 Holer H. Changes in facial expression as a result of plastic surgery in mongoloid children. Aesthetic Plast Surg 1977;1:245-50.

8 Lemperle G, Radu D. Facial plastic surgery in children with Down's syndrome. Plast Reconst Surg 1980;66:337-42.

9 Olbrisch RR. Plastic surgical management of children with Down's syndrome. Br f Plast Surg 1982;35:195-200

10 Rozner L. Facial plastic surgery for Down's syndrome. Lancet 1983;i:1320-3.

11 Harri $\mathrm{K}$, Ohmori $\mathrm{K}$, Torri S. Free gracilis muscle transplantation with microneurovascular anastomoses for the treatment of facial paralysis. Plast Reconstr Surg 1976;57:133-43.

12 Harrison DH. The pectoralis minor vascularised muscle graft for the treatment of unilateral facial palsy. Plast Reconstr Surg 1985;75:206-13.

13 Radovan C. Breast reconstruction after mastectomy using the temporary expander. Plast Reconstr Surg 1982;69:195-208.

\section{Dilated cardiomyopathy, myocarditis, and the bioptome}

Cardiomyopathies are defined as "heart muscle diseases of unknown cause." Our lack of knowledge has acted as a catalyst to extensive research in Europe, Japan, and the United States. In dilated cardiomyopathy cases are recognised as forming a heterogeneous group probably with several aetiologies. For example, recent research in the United States has been looking at the density of $\beta$ adrenergic receptors $^{2}$ and at microvascular changes ${ }^{3}$ which result in damage of an ischaemic type with in each case a final outcome of dilated cardiomyopathy.

The infectious-immune pathogenesis has also been studied for several years. Causal relations are difficult to establish since the clinical course of dilated cardiomyopathy is far from clear. A few reports of incidence have been published giving estimates of some eight to 10 cases per 100000 populationbut these studies were based on patients with symptoms and may represent the tip of an iceberg. ${ }^{4-6}$ Nevertheless, there is evidence to suggest that in some patients at least the likely mechanism is that a viral infection induces an immune reaction which eventually causes irreversible heart failure.

Pivotal to the clinicopathological approach has been the recovery of fresh endomyocardial tissue by bioptome. This instrument is essentially a catheter provided with a cutting device at one end, so that after standard cardiac catheterisation samples of right or left ventricle may be obtained with ease and safety. ${ }^{78}$ Morphological examination of such tissue from patients clinically suspected of having dilated cardiomyopathy has shown the presence of myocarditis. The morphological diagnosis of myocarditis is difficult (as indeed is the clinical diagnosis), for the mere presence of some inflammatory cells in the myocardium is not enough: concomitant changes in the interstitium and adjacent myocardial fibres must be present before the diagnosis can be made. ${ }^{9}$ Published reports of the incidence of myocarditis have varied between $2 \%$ and $63 \% .{ }^{10}$ This wide variation may be due to selection of patients or the underdiagnosis or overdiagnosis of myocarditis, which is often focal. Nevertheless, if five or more biopsy specimens from one or both ventricles are obtained these small tissue samples have been shown to reflect changes in the entire ventricular muscle. ${ }^{11}$

In 1980 an international meeting defined myocarditis as "the presence of inflammatory cells in the myocardium with evidence of fraying of adjacent myocardial fibres but without concomitant sequential fibre necrosis (as it is seen in ischaemic heart disease)." ${ }_{12}$ Sequential biopsies in patients under treatment for active myocarditis have led to a classification into three main groups. ${ }^{13}$ More recently a panel of (predominantly American) pathologists met in Dallas and the definition and classification were reworded, amended, and extended. ${ }^{14}$ Depending on the relation of the inflammatory cell infiltrate, which may be sparse, to the myocardial fibres, the presence of necrosis, and the presence or absence of interstitial fibrosis the three main forms are: active, resolving (healing), and resolved (healed). This categorisation has important therapeutic implications. Patients with active myocarditis confirmed by biopsy have been treated with prednisolone and immunosuppressive agents with resolution of the inflammation and concomitant clinical improvement. ${ }^{15}{ }^{16}$ In the healing stage, too, treatment is beneficial, particularly if there are obvious foci of activity (judged by necrosis) and if the clinical outlook seems poor. If the patient is not severely disabled no more than close follow up may be needed. Once the "healed" phase is reached, however, irrespective of the clinical condition treatment by these agents is useless and if the condition is far advanced cardiac transplantation may offer the only hope.

If the first biopsy specimen shows interstitial fibrosis and foci of fibrous replacement the pathologist may surmise only that the patient had myocarditis in the past. A finding of a hypertrophied, dilated myocardium with varying degrees of fibrosis, though morphologically non-specific, may be diagnosed as dilated cardiomyopathy-provided that other causes of hypertrophy and dilatation have been ruled out.

Virological studies have shown raised antibody titres to Coxsackie $B$ virus in patients with dilated cardiomyopathy and myocarditis, but raised titres may also be found in patients without any evidence of active myocarditis or myocarditis in the past. ${ }^{17-19}$ Myocarditis may also be found in biopsy specimens from patients in whom the results of .

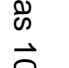 . స్ డ .

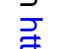

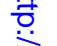 , 임

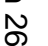
\section{.}

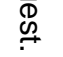
\section{,}


virological investigation are negative. These data suggest that though virus may be causally related the mechanism is more complex than straightforward viral myocarditis; some immunological idiosyncrasy seems likely.

Immunological studies in dilated cardiomyopathy have shown preferential binding of IgG and IgA.${ }^{20}$ Studies of cell mediated immunity have shown abnormal transformation of lymphocytes to phytohaemagglutinin, ${ }^{21}$ that the percentage of circulating $T$ lymphocytes is reduced, ${ }^{22}$ that leucocyte migration is inhibited, ${ }^{23}$ and that $\mathrm{T}$ suppressor cell function is defective..$^{24} \mathrm{~A}$ more recent study found that in two fifths of patients the ratio of helper to suppressor cells was higher than in normal controls. ${ }^{26}$

These studies and other experimental evidence strongly suggest that viral infection evokes an immunological response that results in dilated cardiomyopathy. ${ }^{27-29}$ Possibly the viral infection may trigger antibody production directed at suppressor cells. These antibodies might then affect $T$ cell receptors, which modulate $\beta$ cell function; the result would be increased $\beta$ cell activity and production of autoimmune antibodies. Dysfunction of $\mathrm{T}$ suppressor cells might also affect cell mediated immunity. ${ }^{23}$ Nevertheless, by no means all workers accept the autoimmune hypothesis..$^{30}$

Other avenues of investigation need to be explored in patients with dilated cardiomyopathy, but an infectiousimmune mechanism seems likely to be the cause in about half.

With rare exceptions, ${ }^{19}$ searching for virus in the myocardium using the standard techniques has failed even when immunofluorescence techniques specific for Coxsackie virus have been used. This is not altogether surprising: replication usually takes place early on, and by the time the patient comes to the physician morphologically recognisable virus may no longer be present. ${ }^{31}$ Recently a pilot study using a deoxyribonucleic acid hybridisation probe technique to detect ribonucleic acid sequences specific for Coxsackie $B$ virus has yielded promising results when applied to endomyocardial tissue recovered by bioptome. Even if myocarditis is not present evidence may be found of virus in the myocardium. ${ }^{32}$ This may even apply to patients whose biopsy specimen has shown no evidence of active myocarditis or myocarditis in the past.

The pieces of the jigsaw are now beginning to fall into place, but much work is still necessary. Central to all studies is examination of tissue obtained by bioptome and the accurate diagnosis of myocarditis. Newer diagnostic techniques such as two dimensional echocardiography, Doppler ultrasonography, magnetic resonance, and scintigraphy (particularly gallium scanning) may help in the diagnosis of myocarditis. These techniques are, however, unlikely to replace the study of specimens obtained by bioptome in monitoring the response to treatment. So far as treatment is concerned the studies have been without proper controls. Patients with myocarditis may recover spontaneously ${ }^{28}$ and hence a multicentre controlled trial is mandatory.

\section{ECKHARDT G J OLSEN}

Consultant Histopathologist,

National Heart Hospital,

London W1M 8BA

1 World Health Organisation/International Society and Federation of Cardiology Task Force Report on the definition and classification of cardiomyopathies. Br Heart $\mathcal{F} 1980 ; 44: 672-3$. 2 Bristow MR. The adrenergic nervous system in heart failure. $N$ Engl f Med 1984;311:850-1.

3 Factor SM, Cho S, Sonnenblick EH. Verapamil treatment of cardiomyopathic Syrian hamsters: effects on the micro circulation and the extent of myocardial necrosis. Fed Proc 1981;4:758.

4 Torp A. Incidence of congestive cardiomyopathy. In: Goodwin JF, Hjalmarson A, Olsen EGJ, eds. Congestive cardiomyopathy, Kiruna, Sweden, 1980. Mölndal, Sweden: A B Hässle, 1981: $18-21$.
Bagger JP, Baandrup U, Rasmussen K, Moller M, Vesterlund T. Cardiomyopathy in western Denmark. Br Heart f 1984;52:327-31.

6 Williams DG, Olsen EGJ. Prevalence of overt dilated cardiomyopathy in two regions of England. B Heart f 1985;54:153-5.

7 Sakakibara S, Konno S. Endomyocardial biopsy. Ipn Heart f 1962;3:837-43.

8 Richardson PJ. King's endomyocardial bioptome. Lancet 1974; i:660-1.

9 Olsen EGJ. Histomorphologic relations between myocarditis and dilated cardiomyopathy. In Bolte HD, ed. Viral heart disease. Berlin: Springer-Verlag, 1984:5-12.

10 Fowles RE. Progress of research in cardiomyopathy and myocarditis in the USA. In: Sekiguchi M, Olsen EGJ, Goodwin JF, eds. Myocarditis and related disorders. Proceedings of the international symposium on cardiomyopathy and myocarditis. Berlin: Springer-Verlag, 1985:5-7. (Also published as suppl 1 to Heart and Vessels 1985 .)

11 Baandrup U, Florio RA, Olsen EGJ. Do endomyocardial biopsies represent the state of the rest of the myocardium? A semiquantitative and light microscopic study of single versus multiple biopsies with the King's bioptome. Eur Heart $\mathcal{F}$ 1982;37:171-8.

12 Olsen EGJ. Myocarditis-a case of mistaken identity? Br Heart $\mathcal{f}$ 1983;50:303-11.

13 Richardson PJ, Morgan-Capner P, Daly K, McSorley C, Olsen EGJ. Endomyocardial biopsy and viral heart disease. Verh Disch Ges Herz Kreislaufforsch 1983;49:141-8.

14 Billingham ME, Olsen EGJ, Fengolio JJ Jr, et al. Myocarditis pathology panel, Dallas, Texas, 24 March 1984. Am $\mathcal{J}$ Cardiovasc Path 1986 (in press).

15 Mason JW, Billingham ME, Ricci DR. Treatment of acute inflammatory myocarditis assisted by endomyocardial biopsy. Am $\mathcal{f}$ Cardiol 1980;45:1037-44

16 Daly K, Richardson PJ, Olsen EGJ, et al. Acute myocarditis. Role of histological and virological examination in the diagnosis and assessment of immunosuppressive treatment. Br Heart 7 1984;51:30-5.

17 Cambridge G, MacArthur CGC, Waterson AP, Goodwin JF, Oakley CM. Antibodies to Coxsackie $B$ viruses in congestive cardiomyopathy. Br Heart $\mathcal{f}$ 1979;41:692-6.

18 Richardson PJ. Viral myocarditis and cardiomyopathy. In: Maseri A, ed. Hammersmith cardiology workshop series. Vol 2. New York: Raven Press, 1985:111-7.

19 Kawai C. Idiopathic cardiomyopathy: a study on the infectious-immune theory as a cause of the disease. Jpn Circ $\mathcal{X}$ 1971;35:765-70.

20 Bolte HD, Schultheiss P. Immunological results in myocardial diseases. Postgrad Med $\mathcal{f}$ 1978;54:500-3

21 Das SK, Petty RE, Meengs WL, Turbergen DJ. Cell mediated immunity in cardiomyopathy. Circulation 1976;53, 54:(suppl 2):22.

22 Sachs RN, Lanfranchi J. Cardiomyopathies primitives et anomalies immunitaires. Coeur et Medecine Interne 1978;17:193-8.

23 Das SK, Stein LD, Reynolds RT, Thebert P, Cassidy JT. Immunologic studies in cardiomyopathy and pathophysiologic implications. In: Goodwin JF, Hjalmarson A, Olsen EGJ, eds. pathy and pathophysiologic implications. In: Goodwin JF, Hjalmarson A, Olsen EGJ, eds.

24 Fowles RE, Biober CP, Stinson EB. Defective in vitro suppressor cell function in idiopathic congestive cardiomyopathy. Circulation 1979;59:483-91.

25 Eckstein R, Mempel W, Bolte HD. Reduced suppressor cell activity in congestive cardiomyopathy and in myocarditis. Circulation 1982;65:1224-9.

26 Sanderson JE, Koech D, Iha D, Ojiambo HP. T-lymphocyte subsets in idiopathic dilated cardiomyopathy. Am $\mathcal{F}$ Cardiol 1985;55:755-8.

27 Ablemann H, Miklozek C, Modlin JF. The role of viruses in the aetiology of congestive cardiomyopathy. In: Goodwin JF, Hjalmarson A, Olsen EGJ, eds. Congestive cardiomyopathy, Kiruna, Sweden, 1980. Mölndal, Sweden: A B Hässle, 1981:76-84.

28 Goodwin JF. On the possibility of viral myocarditis as an important aetiologic agent of cardiomyopathy. In: Sekiguchi M, Olsen EGJ, Goodwin JF, eds. Myocarditis and related disorders. Proceedings of the international symposium on cardiomyopathy and myocarditis. Berlin: Springer-Verlag, 1985:4. (Also published as suppl 1 to Heart and Vessels 1985.)

29 Sekiguchi M, Yu Zu-Xi, Hasumi M, Hiroe M, Morimoto S, Nishikawa T. Histopathologic and ultrastructural observations of acute and convalescent myocarditis: a serial endomyocardial biopsy study. In: Sekiguchi M, Olsen EGJ, Goodwin JF, eds. Proceedings of the international symposium on cardiomyopathy and myocarditis. Berlin: Springer-Verlag, 1985:143-53.

30 Thompson RA, Trueman T, Harvey MR, Haschett M, Littler WA, Retieff L. Immunological methods and cardiomyopathy. Lancet 1980;i:47.

A A

32 Bowles NE, Richardson PJ, Olsen EGJ, Archard LC. Detection of Coxsackie B virus-specific RNA sequences in myocardial biopsy samples from cases of myocarditis and dilated cardiomyopathy. Lancet 1986;(in press).

\section{Whatever happened to the Black report?}

Like the Bible, the Black report on inequalities in health is much quoted, occasionally read, and largely ignored when it comes to action. ${ }^{.}$Six years after its publication virtually none of its 37 recommendations have been implemented (even the 23 that would have cost little or nothing), and all the data available suggest that the gap between the rich and poorboth in their income and in their health-is widening.

Worried by the plight of the growing number of poor in Britain, the British Medical Association, the Trades Union Congress, and the Health Education Council joined together last week and held a conference to try to find a way forward. The mood of the conference was that radical measures were necessary, and Sir Richard O'Brien, formerly chairman of the Manpower Services Commission and speaking at the conference in his role as chairman of the Archbishop of Canterbury's commission on urban priority areas, ${ }^{2}$ suggested 